\title{
Brevibacterium album sp. nov., a novel actinobacterium isolated from a saline soil in China
}

Correspondence

Wen-Jun Li

wjli@ynu.edu.cn

\author{
Shu-Kun Tang, ${ }^{1} \dagger$ Yun Wang, ${ }^{2} \dagger$ Peter Schumann, ${ }^{3}$ Erko Stackebrandt, ${ }^{3}$ \\ Kai Lou, ${ }^{2}$ Cheng-Lin Jiang, ${ }^{1}$ Li-Hua $\mathrm{Xu}^{1}$ and Wen-Jun $\mathrm{Li}^{1}$
}

\author{
${ }^{1}$ The Key Laboratory for Microbial Resources of the Ministry of Education, PR China, and \\ Laboratory for Conservation and Utilization of Bio-Resources, Yunnan Institute of Microbiology, \\ Yunnan University, Kunming 650091, PR China \\ ${ }^{2}$ Xinjiang Institute of Microbiology, Xinjiang Academy of Agricultural Science, Urumqi, \\ Xinjiang 830091, PR China \\ ${ }^{3} \mathrm{DSMZ}$ - Deutsche Sammlung von Mikroorganismen und Zellkulturen $\mathrm{GmbH}$, Inhoffenstr. 7b, \\ D-38124 Braunschweig, Germany
}

\begin{abstract}
A novel Gram-positive, rod-shaped actinobacterium, designated strain YIM $90718^{\top}$, was isolated from a saline soil in Xinjiang province, north-west China, and subjected to polyphasic taxonomy. The peptidoglycan type was $\mathrm{A} 1 \gamma$ and the cell-wall sugars contained galactose. Phospholipids were phosphatidylglycerol and diphosphatidylglycerol. The predominant menaquinone was MK-

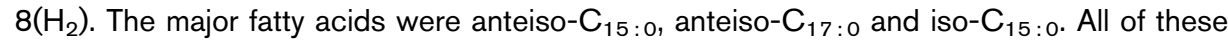
chemotaxonomic data assigned the new isolate YIM $90718^{\top}$ consistently to the genus Brevibacterium. Phylogenetic analysis based on 16S rRNA gene sequences revealed that strain YIM $90718^{\top}$ formed a distinct phyletic lineage in the genus Brevibacterium and showed the highest sequence similarity (96.2\%) to Brevibacterium samyangense SST- ${ }^{\top}$ and low similarity $(<95.5 \%)$ to other species of the genus Brevibacterium. On the based of the polyphasic evidence, a novel species, Brevibacterium album sp. nov., is proposed, with the type strain YIM $90718^{\top}\left(=\mathrm{DSM} 18261^{\top}=\right.$ KCTC $19173^{\top}=$ CCTCC AB 206112 $\left.{ }^{\top}\right)$.
\end{abstract}

The genus Brevibacterium was first proposed by Breed (1953) for some Gram-positive, non-spore-forming, nonbranching rods formerly classified as the genus 'Bacterium'. The description of the genus was later emended and restricted only to species that correspond to the type species Brevibacterium linens on the basis of morphological and chemotaxonomic characteristics (Collins et al., 1980). The genus currently contains 16 species with validly published names isolated from clinical specimens, dairy products, poultry and terrestrial and marine environments. While this paper was in preparation, Brevibacterium samyangense, isolated from beach sediment, was reported (Lee, 2006). In this article, strain YIM 90718 ${ }^{\mathrm{T}}$, isolated from a saline soil, is described as a novel member of the genus Brevibacterium based on polyphasic taxonomy.

Strain YIM $90718^{\mathrm{T}}$ was isolated from a saline soil sample collected from Xinjiang, after 2 weeks incubation at $37{ }^{\circ} \mathrm{C}$ on modified ISP medium 5. This medium contained $\left(\mathrm{g} \mathrm{l}^{-1}\right)$ : L-asparagine, 1.0; glycerol, 10.0; yeast extract, 5.0; $\mathrm{K}_{2} \mathrm{HPO}_{4}, 1.0 ; \mathrm{KNO}_{3}, 5.0 ; \mathrm{KCl}, 150$; and agar, 15.0. $\mathrm{KCl}$ was

†These authors contributed equally to this work.

The GenBank/EMBL/DDBJ accession number for the 16S rRNA gene sequence of strain YIM $90718^{\top}$ is EF158852. sterilized separately before being added to the medium. The $\mathrm{pH}$ of the medium was adjusted to $\mathrm{pH}$ 7.5. The strain was maintained on ISP 5 slants (Shirling \& Gottlieb, 1966) containing $5 \%(\mathrm{w} / \mathrm{v}) \mathrm{NaCl}$ at $4{ }^{\circ} \mathrm{C}$ and as glycerol suspensions $(20 \%, \mathrm{v} / \mathrm{v})$ at $-20{ }^{\circ} \mathrm{C}$. Biomass for chemical and molecular studies was obtained by cultivation in shaken flasks (about 150 r.p.m.) using ISP medium 5 [5\% (w/v) $\mathrm{NaCl}, \mathrm{pH} 7.5$ ] at $37^{\circ} \mathrm{C}$ for 1 week.

Cell morphology was determined using cultures grown for $6,12,16,24$ and $72 \mathrm{~h}$ on modified ISP 5 agar medium supplemented with $5 \%(\mathrm{w} / \mathrm{v}) \mathrm{NaCl}$ at $37^{\circ} \mathrm{C}$. Gram staining was carried out by the standard Gram reaction and was confirmed by using the $\mathrm{KOH}$ lysis test method (Cerny, 1978). Cell motility was confirmed by the presence of turbidity throughout tubes of semisolid medium (Leifson, 1960). Morphological characteristics of the strain were observed by light microscopy (model BH 2; Olympus) and by transmission electron microscopy with a model $\mathrm{H}$ 800 transmission electron microscope (Hitachi). Growth was tested at $4,10,20,28,37,45,55$ and $65{ }^{\circ} \mathrm{C}$ on ISP medium 5 containing $5 \%(\mathrm{w} / \mathrm{v}) \mathrm{NaCl}$. For $\mathrm{NaCl}$ tolerance experiments, modified ISP medium 5 was used as the basal medium. The following $\mathrm{NaCl}$ concentrations (w/v) were used: $0,1,3,5,10,15,20,25$ and $30 \%$. The $\mathrm{pH}$ range for 
growth was investigated between $\mathrm{pH} 4.0$ and 10.0 at intervals of $1 \mathrm{pH}$ unit using the following buffer systems: $\mathrm{pH} 4.0-5.0, \quad 0.1 \mathrm{M}$ citric acid/0.1 M sodium citrate; pH 6.0-8.0, $0.1 \mathrm{M} \mathrm{KH}_{2} \mathrm{PO}_{4} / 0.1 \mathrm{M} \mathrm{NaOH}$; pH 9.0-10.0, $0.1 \mathrm{M} \mathrm{NaHCO} / 0.1 \mathrm{M} \mathrm{Na}_{2} \mathrm{CO}_{3}$. Catalase activity was determined by production of bubbles after the addition of a drop of $3 \% \mathrm{H}_{2} \mathrm{O}_{2}$. Oxidase activity was observed by oxidation of tetramethyl-p-phenylenediamine. Carbon source utilization tests were carried out using GP2 microplates of the Microlog system (Biolog; 95 substrates). Some physiological properties were tested by using the API CORYNE and API ZYM strips (bioMérieux) according to the manufacturer's instructions. The morphological, cultural and physiological properties of strain YIM $90718^{\mathrm{T}}$ are given in Table 1 and in the species description.

Peptidoglycan was purified and the cell-wall amino acids and peptides in cell-wall hydrolysates were analysed by twodimensional ascending TLC on cellulose plates using the solvent system of Schleifer \& Kandler (1972). The cell-wall sugars were analysed according to the procedures developed by Hasegawa et al. (1983). Polar lipids were extracted, examined by two-dimensional TLC and identified using procedures described previously (Minnikin et al., 1984). Menaquinones were isolated according to Minnikin et al. (1984) and separated by HPLC (Kroppenstedt, 1982). Cellular fatty acid analysis was performed as described by Sasser (1990) using the Microbial Identification System (MIDI). The peptidoglycan type of YIM $90718^{\mathrm{T}}$ was $\mathrm{A} 1 \gamma$ and galactose was the cell-wall sugar. Phospholipids contained phosphatidylglycerol and diphosphatidylglycerol. The predominant menaquinone was $\mathrm{MK}-8\left(\mathrm{H}_{2}\right)$. The major fatty acids were anteiso- $\mathrm{C}_{15: 0}$, anteiso- $\mathrm{C}_{17: 0}$ and iso- $\mathrm{C}_{15: 0}$. All of

Table 1. Differential phenotypic characteristics between strain YIM $90718^{\top}$ and its nearest phylogenetic neighbour, $B$. samyangense SST-8 ${ }^{\mathrm{T}}$

Data for strain SST- $8^{\mathrm{T}}$ were taken from Lee (2006).

\begin{tabular}{|c|c|c|}
\hline Characteristic & Strain YIM $90718^{\mathrm{T}}$ & B. samyangense $\mathrm{SST}-8^{\mathrm{T}}$ \\
\hline Colony colour & White & Bright yellow \\
\hline Rod-coccus cycle & - & + \\
\hline $\begin{array}{l}\text { Temperature range } \\
\left({ }^{\circ} \mathrm{C}\right)\end{array}$ & $28-45$ & $10-45$ \\
\hline $\mathrm{pH}$ range & $6-8$ & $6.1-10.1$ \\
\hline Gelatin hydrolysis & + & - \\
\hline \multicolumn{3}{|l|}{ Utilization of: } \\
\hline Tween 40 & - & + \\
\hline Sucrose & - & + \\
\hline$\alpha$-D-Lactose & - & + \\
\hline D-Malic acid & + & - \\
\hline$\alpha$-Glucosidase & - & + \\
\hline$\beta$-Galactosidase & - & + \\
\hline$\alpha$-Chymotrypsin & + & - \\
\hline Polar lipids* & DPG, PG & PG \\
\hline
\end{tabular}

${ }^{\star}$ DPG, Diphosphatidylglycerol; PG, phosphatidylglycerol. these features are consistent with the chemotaxonomic description of the genus Brevibacterium (Collins et al., 1980). Details of the phospholipids and menaquinones and the cellular fatty acid profile are reported in the species description.

Extraction of genomic DNA and PCR amplification of the 16S rRNA gene were done as described by Li et al. (2007). Multiple alignments with sequences of the most closely related members of Brevibacterium and calculations of levels of sequence similarity were carried out using CLUSTAL_X (Thompson et al., 1997). Phylogenetic analyses were performed using three tree-making algorithms: the neighbour-joining (Saitou \& Nei, 1987), maximumlikelihood (Felsenstein, 1981) and maximum-parsimony (Fitch, 1971) methods. A phylogenetic tree was constructed using the neighbour-joining method from $K_{\text {nuc }}$ values (Kimura, 1980) using MEGA version 2.1 (Kumar et al., 2001). The topology of the phylogenetic tree was evaluated by the bootstrap resampling method of Felsenstein (1985) with 1000 replicates. Genomic DNA of strain YIM $90718^{\mathrm{T}}$ for the determination of $\mathrm{G}+\mathrm{C}$ content was prepared according to the method of Marmur (1961). The G+C content of the DNA was determined by reversed-phase HPLC of nucleosides according to Mesbah et al. (1989).

A neighbour-joining phylogenetic tree (Fig. 1) based on 16S rRNA gene sequence comparison clearly showed that strain YIM $90718^{\mathrm{T}}$ belongs to the genus of Brevibacterium and forms a distinct subclade with B. samyangense. The $16 \mathrm{~S}$ rRNA gene sequence similarity between strain YIM $90718^{\mathrm{T}}$ and its nearest neighbour, B. samyangense SST $-8^{\mathrm{T}}$, was $96.2 \%$, and low $16 \mathrm{~S}$ rRNA gene sequence similarity $(<95.5 \%)$ was revealed with other species of the genus

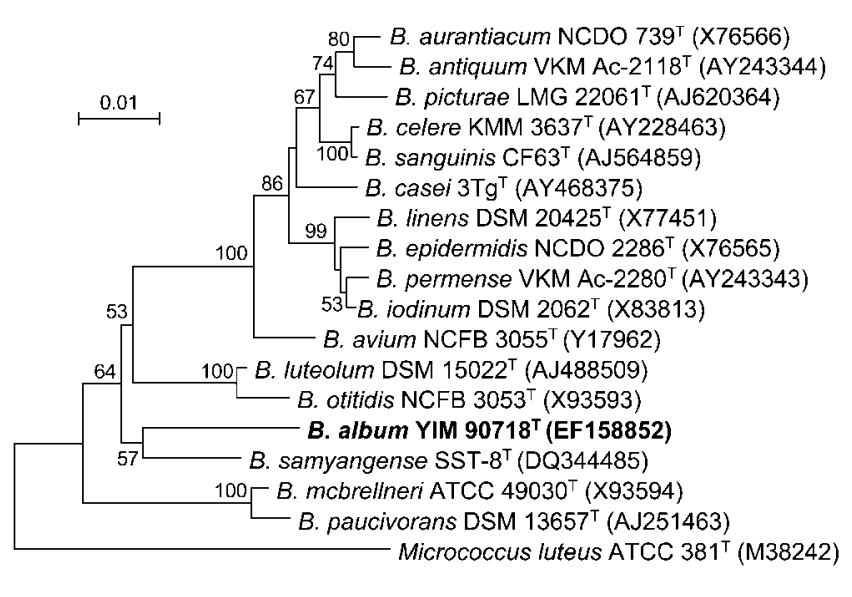

Fig. 1. Phylogenetic dendrogram obtained by distance matrix analysis of 16S rRNA gene sequences, showing the position of strain YIM $90718^{\top}$ and its phylogenetic neighbours. Numbers at branch nodes are bootstrap values (1000 resamplings; only values over $50 \%$ are given). The sequence of Micrococcus luteus ATCC $381^{\top}$ was used as an outgroup. Bar, $1 \%$ sequence divergence. 
Brevibacterium. The $\mathrm{G}+\mathrm{C}$ content of the DNA was $70.0 \mathrm{~mol} \%$.

On the basis of the phenotypic, chemotaxonomic and phylogenetic data, strain YIM $90718^{\mathrm{T}}$ merits recognition within a novel species of the genus Brevibacterium, for which we propose the name Brevibacterium album sp. nov.

\section{Description of Brevibacterium album sp. nov.}

Brevibacterium album (al'bum. L. neut. adj. album white).

Cells are aerobic, Gram-positive, motile, catalase-positive, oxidase-negative, non-spore-forming rods, $1.8 \times 4.0$ $5.0 \mu \mathrm{m}$. Colonies are white on most media tested. Colonies are smooth, circular, opaque and approximately $1-2 \mathrm{~mm}$ in diameter after $48 \mathrm{~h}$ incubation at $37^{\circ} \mathrm{C}$ on ISP medium 5 containing $5 \%(\mathrm{w} / \mathrm{v}) \mathrm{NaCl}$. Growth occurs in the temperature, $\mathrm{pH}$ and salt ranges of $28-45^{\circ} \mathrm{C}, \mathrm{pH} 6-8$, $0-10 \% \mathrm{NaCl}(\mathrm{w} / \mathrm{v}), 0-20 \% \mathrm{KCl}(\mathrm{w} / \mathrm{v})$ and $0-30 \%$ $\mathrm{MgCl}_{2} \cdot 6 \mathrm{H}_{2} \mathrm{O}(\mathrm{w} / \mathrm{v})$. Good growth occurs at $37^{\circ} \mathrm{C}$, $\mathrm{pH} 7.5,0-5 \%(\mathrm{w} / \mathrm{v}) \mathrm{NaCl}, 0-10 \% \mathrm{KCl}(\mathrm{w} / \mathrm{v})$ and 0 $15 \% \mathrm{MgCl}_{2} \cdot 6 \mathrm{H}_{2} \mathrm{O}(\mathrm{w} / \mathrm{v})$. The following substrates are utilized as sole carbon sources for growth in Biolog GP2 microplates: $\beta$-cyclodextrin, Tween $80, \mathrm{~N}$-acetyl-D-glucosamine, L-fucose, D-gluconic acid, myo-inositol, lactulose, D-mannitol, methyl $\beta$-D-galactoside, methyl $\alpha$-D-glucoside, palatinose, L-mannose, salicin, trehalose, turanose, D-malic acid, succinic acid, D-alanine, L-alanyl glycine, putrescine, uridine $5^{\prime}$-monophosphate and fructose 6-phosphate. The following substrates are not utilized in the Biolog GP2 system: $\alpha$-cyclodextrin, dextrin, glycogen, inulin, mannan, Tween 40, $N$-acetyl- $\beta$-D-mannosamine, amygdalin, Larabinose, D-arabitol, arbutin, cellobiose, D-fructose, Dgalactose, D-galacturonic acid, gentiobiose, $\alpha$-D-glucose, $\alpha$-D-lactose, maltose, maltotriose, D-mannose, melezitose, melibiose, methyl $\alpha$-D-galactoside, 3-methyl glucose, methyl $\beta$-D-glucoside, methyl $\alpha$-D-mannoside, D-psicose, raffinose, D-ribose, sedoheptulosan, D-sorbitol, stachyose, sucrose, D-tagatose, xylitol, D-xylose, acetic acid, $\alpha-, \beta$ - and $\gamma$-hydroxybutyric acid, $p$-hydroxyphenylacetic acid, $\alpha$ ketoglutaric acid, $\alpha$-ketovaleric acid, lactamide, D-lactic acid methyl ester, L-lactic acid, L-malic acid, methyl pyruvate, monomethyl succinate, propionic acid, pyruvic acid, succinamic acid, $\mathrm{N}$-acetyl-L-glutamic acid, L-alaninamide, L-alanine, L-asparagine, L-glutamic acid, glycyl Lglutamic acid, L-pyroglutamic acid, L-serine, 2,3-butanediol, glycerol, adenosine, 2'-deoxyadenosine, inosine, thymidine, uridine, adenosine $5^{\prime}$-monophosphate, thymidine 5'-monophosphate, glucose 1-phosphate, glucose 6phosphate and DL- $\alpha$-glycerol phosphate. In the API CORYNE system, tests for pyrazinamidase, pyrrolidonyl arylamidase, alkaline phosphatase, gelatin hydrolysis and acid production from D-ribose are positive. Tests for nitrate reduction, $\beta$-glucuronidase, $\beta$-galactosidase, $\alpha$ glucosidase, $N$-acetyl- $\beta$-glucosaminidase, $\quad \beta$-glucosidase (aesculin hydrolysis), urease and acid production from Dglucose, D-xylose, D-mannitol, maltose, D-lactose, sucrose and glycogen are negative. Using the API ZYM system, acid and alkaline phosphatase, esterase (C4), esterase lipase (C8), leucine arylamidase, valine arylamidase, cystine arylamidase, trypsin, $\alpha$-chymotrypsin and naphthol-ASBI-phosphohydrolase tests are positive. Lipase (C14), $\alpha$-galactosidase, $\beta$-galactosidase, $\beta$-glucuronidase, $\alpha$-glucosidase, $\beta$-glucosidase, $N$-acetyl- $\beta$-glucosaminidase, $\alpha$-mannosidase and $\alpha$-fucosidase tests are negative. The peptidoglycan is A1 $\gamma$, meso-diaminopimelic acid directly cross-linked. Cell-wall sugar contains galactose. The phospholipids are phosphatidylglycerol and diphosphatidylglycerol. The menaquinones are MK- $8\left(\mathrm{H}_{2}\right), \mathrm{MK}-7\left(\mathrm{H}_{2}\right)$, MK-6 $\left(\mathrm{H}_{2}\right)$, MK-8, MK-6 and MK-9 $\left(\mathrm{H}_{2}\right)$ (ratio of peak areas, $76: 10: 5: 3: 2: 1)$. The fatty acid profile contains anteiso- $\mathrm{C}_{15: 0}(58.71 \%)$, anteiso- $\mathrm{C}_{17: 0}(19.0 \%)$, iso- $\mathrm{C}_{15: 0}$ $(12.29 \%)$ and iso- $\mathrm{C}_{16: 0}(7.24 \%)$. The $\mathrm{G}+\mathrm{C}$ content of the DNA of the type strain is $70.0 \mathrm{~mol} \%$.

The type strain is YIM $90718^{\mathrm{T}}\left(=\mathrm{DSM} 18261^{\mathrm{T}}=\mathrm{KCTC}\right.$ $19173^{\mathrm{T}}=$ CCTCC AB $206112^{\mathrm{T}}$ ), isolated from a saline soil in the north-west of China.

\section{Acknowledgements}

This research was supported by the National Basic Research Program of China (no. 2004CB719601), the National Natural Science Foundation of China (nos 30560001 and 30600001), the Yunnan Provincial International Cooperative Program (no. 2005GH21), the Ministry of Science of Technology, PR China (2006DFA33550), and the Open Project Program of the Extremophiles Lab of Xinjiang (no. XJYS0203-2005-01). W.-J. L. was supported by the Program for New Century Excellent Talents in University.

\section{References}

Breed, R. S. (1953). The families developed from Bacteriaceae Cohn with a description of the family Brevibacteriaceae. Rias Commun VI Int Congr Microbiol Roma 1, 10-15.

Cerny, G. (1978). Studies on aminopeptidase for the distinction of Gram-negative from Gram-positive bacteria. Eur J Appl Microbiol Biotechnol 5, 113-122.

Collins, M. D., Jones, D., Keddie, R. M. \& Sneath, P. H. A. (1980). Reclassification of Chromobacterium iodinum (Davis) in a redefined genus Brevibacterium (Breed) as Brevibacterium iodinum nom. rev.; comb. nov. J Gen Microbiol 120, 1-10.

Felsenstein, J. (1981). Evolutionary trees from DNA sequences: a maximum likelihood approach. J Mol Evol 17, 368-376.

Felsenstein, J. (1985). Confidence limits on phylogenies: an approach using the bootstrap. Evolution 39, 783-791.

Fitch, W. M. (1971). Toward defining the course of evolution: minimum change for a specific tree topology. Syst Zool 20, 406-416.

Hasegawa, T., Takizawa, M. \& Tanida, S. (1983). A rapid analysis for chemical grouping of aerobic Actinomycetes. J Gen Appl Microbiol 29, 319-322.

Kimura, M. (1980). A simple method for estimating evolutionary rates of base substitutions through comparative studies of nucleotide sequences. J Mol Evol 16, 111-120.

Kroppenstedt, R. M. (1982). Separation of bacterial menaquinones by HPLC using reverse phase (RP 18) and a silver loaded ion exchanger as stationary phases. J Liq Chromatogr 5, 2359-2367. 
Kumar, S., Tamura, K., Jakobsen, I.-B. \& Nei, M. (2001). MEGA2: molecular evolutionary genetics analysis software. Bioinformatics $\mathbf{1 7}$, 1244-1245.

Lee, S. D. (2006). Brevibacterium samyangense sp. nov., an actinomycete isolated from a beach sediment. Int J Syst Evol Microbiol 56, 1889-1892.

Leifson, E. (1960). Atlas of Bacterial Flagellation. London: Academic Press.

Li, W.-J., Xu, P., Schumann, P., Zhang, Y.-Q., Pukall, R., Xu, L.-H., Stackebrandt, E. \& Jiang, C.-L. (2007). Georgenia ruanii sp. nov., a novel actinobacterium isolated from forest soil in Yunnan (China), and emended description of the genus Georgenia. Int J Syst Evol Microbiol 57, 1424-1428.

Marmur, J. (1961). A procedure for the isolation of deoxyribonucleic acid from microorganisms. J Mol Biol 3, 208-218.

Mesbah, M., Premachandran, U. \& Whitman, W. B. (1989). Precise measurement of the $\mathrm{G}+\mathrm{C}$ content of deoxyribonucleic acid by highperformance liquid chromatography. Int J Syst Bacteriol 39, 159-167.
Minnikin, D. E., O’Donnell, A. G., Goodfellow, M., Alderson, G., Athalye, M., Schaal, A. \& Parlett, J. H. (1984). An integrated procedure for the extraction of bacterial isoprenoid quinones and polar lipids. J Microbiol Methods 2, 233-241.

Saitou, N. \& Nei, M. (1987). The neighbor-joining method: a new method for reconstructing phylogenetic trees. Mol Biol Evol 4, 406-425.

Sasser, M. (1990). Identification of bacteria by gas chromatography of cellular fatty acids. USFCC Newsl 20, 16.

Schleifer, K. H. \& Kandler, O. (1972). Peptidoglycan types of bacterial cell walls and their taxonomic implications. Bacteriol Rev 36, 407-477.

Shirling, E. B. \& Gottlieb, D. (1966). Methods for characterization of Streptomyces species. Int J Syst Bacteriol 16, 313-340.

Thompson, J. D., Gibson, T. J., Plewniak, F., Jeanmougin, F. \& Higgins, D. G. (1997). The CLUSTAL_X windows interface: flexible strategies for multiple sequence alignment aided by quality analysis tools. Nucleic Acids Res 25, 4876-4882. 